\title{
THE WESTERN TRYPILLIA CULTURE HOUSE FROM THE SETTLEMENT OF KAMIANETS-PODILSKYI, TATARYSKY, $3950-3900$ BCE
}

This paper presents the results of excavations of the Western Trypillia culture house at the settlement of Kamianets-Podilskyi, Tatarysky. We discuss the house construction techniques, location of the interior details and house collapse. Analogies from other regions of the Western Trypillia culture made possible the conclusions on spread of the house construction techniques and traditions of interior location from the Middle Dniester region to the Southern Buh and Dnipro interfluve.

Keywords: Cucuteni-Trypillia cultural complex, Western Trypillia culture, ploshchadka, house, interior.

Introduction. The current state of Trypillia research is characterized by the imbalance of empirical data representing different regions of the Western Trypillia culture (hereinafter - WTC; Рижов 2007) and Eastern Trypillia culture (hereinafter - ETC; Цвек 2006; the term "Trypillia» is used to characterize both the ETC and WTC or specify chronological position of a site, e. g., «Trypillia BII»). To a certain extent this regional bias was caused by the discovery of the Trypillia mega-sites in the Southern Buh and Dnipro interfluve in the late 1960s and further involvement of the majority of experts into the excavations and surveys in this area. Intensive fieldwork in the Southern Buh and Dnipro interfluve in 1960s the beginning of 1990s even led to the formation of "schools" in Ukrainian Trypillia archaeology (Отрощенко 2015). At the same time, even such well-studied areas as the Middle Dniester region still lack complete precise chronological sequences of sites and clear-cut division of the local groups. Therefore, publication of data from the museum collections and recent excavations in these regions is one of the key goals of the Trypillia research.

(C) O. V. DIACHENKO, I. SOBKOWIAK-TABAKA,

Ie. Iu. LEVINZON, 2021
This paper aims to introduce the results of excavations of the house remains at the WTC settlement of Kamianets-Podilskyi, Tatarysky in 2019. Ploshchadka, or layers of burnt clay, ceramics and tools representing the house remains, was already briefly described in the preliminary publication (Дяченко та ін. 2019), but it is reasonable to discuss the house construction techniques and its interior in details. Let us begin with the introduction to our excavations at this site.

Excavations at the WTC settlement of Kamianets-Podilskyi, Tatarysky. The WTC settlement of Kamianets-Podilskyi, Tatarysky is located on the hill-shaped ledge of a plateau to the south of Kamianets-Podilskyi castle (fig. 1). The site has been known since 1926. Collections from intensive surface surveys on its surface are kept by the Kamianets-Podilskyi State Historical Museum-Preservation and the Archaeological Laboratory of the Ivan Ohienko Kamianets-Podilskyi National University (Левінзон 2018; 2019). S. Ryzhov attributes Kamianets-Podilskyi, Tatarysky to the formation phase of Petreni group (Рижов 2003), while T. Tkachuk refers this site to the second phase of Mereşeuca group (Ткачук 2015; cf. Ткачук 2019). Considering the two radiocarbon dates obtained for Ploshchadka 1 discussed below and relative chronology of the WTC settlements, Kamianets-Podilskyi, Tatarysky is dated to the range of $3950-3900$ BCE. The settlement may be synchronized with Trostianchyk located in the Buh region and Nebelivka located in the Southern Buh and Dnipro interfluve (Diachenko, Sobkowiak-Tabaka 2020; also see: Rud et al. 2019; Chapman et al. 2020).

Our fieldwork at the WTC settlement of Kamianets-Podilskyi, Tatarysky, is conducted in frames of the research project «Dynamics of prehistoric culture: Comprehensive analysis of records from 


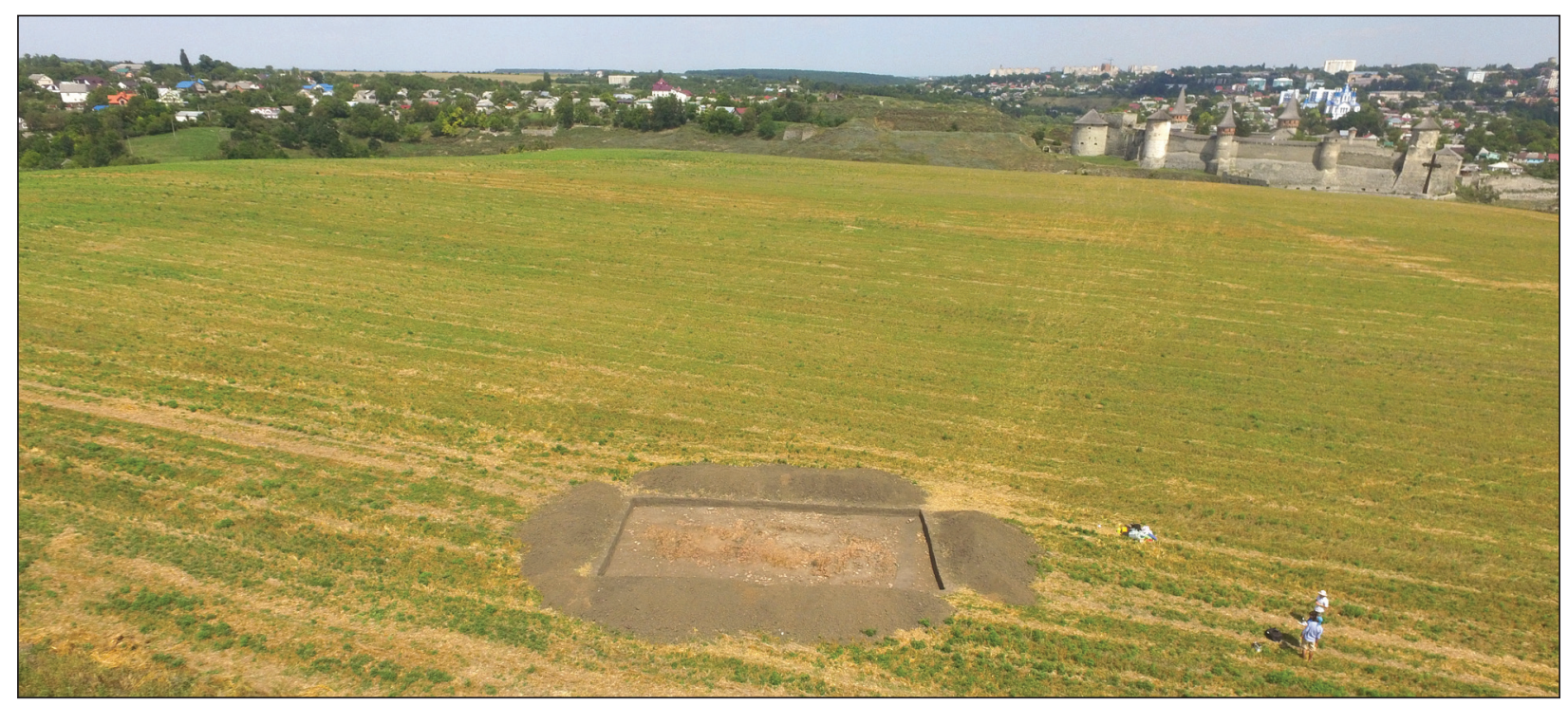

Fig. 1. Kamianets-Podilskyi, Tatarysky, view on the site from the south (photo by Iryna Pustynnikova)

Southeastern and Central Europe» funded by the National Science Center of Poland (2018/29/B/ HS3/01201; Iwona Sobkowiak-Tabaka, PI). Due to the lockdown, we plan three excavation seasons instead of the initially planned two. Ploshchadka, pottery kilns and a part of ditch were explored during the excavation campaigns of 2019 and 2020 preceded by geophysical surveys, which identified the settlement structure composed by elliptical circuits of dwellings (T. Herbich headed the team of geophysicists from the Institute of Archaeology and Ethnology of the Polish Academy of Sciences). Excavations will be continued in 2021.

House 1: Construction techniques, interior and collapse. Ploshchadka 1 belongs to a cluster composed of four houses, which is located in the outer construction circuit of the settlement. Ploshchadka had a nearly rectangular shape. This feature reaching a size of c. $11.6 \times 4 \mathrm{~m}$ was oriented along the west-east axis with a small northwest - southeast deviation (figs. 1; 2). Cultural layer in its perimeter was intensively filled by pottery shreds and bones (fig. 2). Let us start the discussion of this feature with the house construction techniques. As usually, post-holes were not identified below the ploshchadka. This brings us to the widely spread suggestion on the wooden base, into which the posts were nested. The assumption is confirmed by the relatively low elevation of some finds in the perimeter of Ploshchadka 1 comparing to the elevation of burnt daub and majority of pottery shreds. The two stones, including the used grinding stone, suggesting their use in order to strength the construction, probably mark the northeastern, northwestern and southwestern corners of the dwelling (fig. 2).

Layer of burnt daub represents the floor of the upper storey of the house. Imprints on the down side of daub fragments make possible the identification of construction techniques of the wooden carcass of the floor. The latter was composed of relatively thick beams (exceeding 8-10 $\mathrm{cm}$ in thickness and width) of nearly square shape in profile or semi-rounds, which were placed at the distance of c. $1 \mathrm{~m}$ one from the other (fig. 3: A). Beams supported the decks of a thickness exceeding $2-3 \mathrm{~cm}$, which edges were placed one on top of the other in a form of a tortoise shell (fig. 3: B). The preserved width of decks traced on imprints reaches $10 \mathrm{~cm}$. Beams and decks were placed in parallel to the short walls of the house. In some parts of Ploshchadka 1 we have indicated the imprints of wooden branches (composed of joined twigs) and twigs of a diameter of $5-6 \mathrm{~mm}$ which were placed above the decks.

The wooden construction was covered by two layers of daub. The first layer (counting down - top) of a thickness of $10-11 \mathrm{~cm}$ was produced of clay with organic admixture (chaff). Comparing our feature to the dwellings in other areas of the WTC, for example, Tomashivka group houses in the Southern Buh and Dnipro interfluve (e. g., Chernovol 2012), we may admit the average intensiveness of organic admixture. Daub with organic admixture was not evenly spread across ploshchadka, mainly being found in the residential area (see below). Moreover, the intensiveness of the admixture varies in different fragments of daub. Admixture of sand in the first layer of daub is relatively small. The second layer of daub of a thickness of c. $7-8 \mathrm{~cm}$, covering the first one, is represented by clay with very small organic admixture or lack of organics and intensive admixture of sand. The top surface of the second layer, or the actual floor of the second storey, was smoothed.

The upper storey of the house was subdivided into the two rooms, i. e. residential area of a length of c. $7.4 \mathrm{~m}$ in the eastern part and entrance room of a length of c. $4.2 \mathrm{~m}$ in the western part. This subdivision is marked by a thin hiatus detected in parallel to the short walls of the house. Interior details were detected only in residential area (fig. 2). These are the oven and interior element, which shape and size is not possible to reconstruct. 

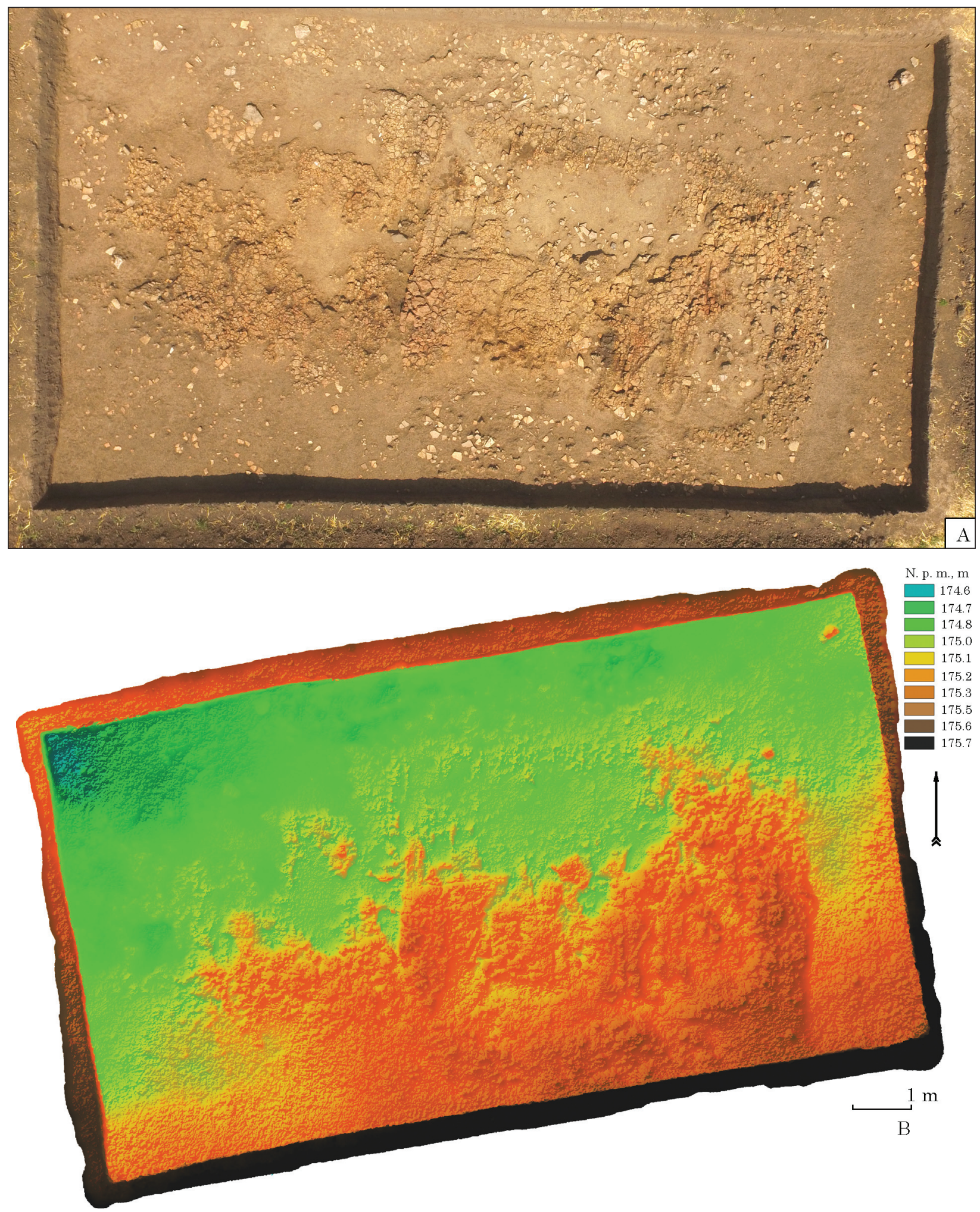

Fig. 2. Kamianets-Podilskyi, Tatarysky, Ploshchadka 1: A — aerial photo by Iryna Pustynnikova; B - elevation model by Mateusz Stróżyk

The oven of a size of c. $1.6 \times 1.4 \mathrm{~m}$ was located to the right from the entrance to residential area (fig. 4). Its base was shaped as a thick layer (exceeding $15 \mathrm{~cm}$ ) of daub without organic admixtures placed on the wooden construction of the floor of the upper storey. In some cases such thick layers of clay located with the identical location in a house per se indicate the heaths (е. g., Черновол 2019). However, in our case holes from the wooden construction of walls of the oven were identified from its western side (fig. 5). Oven-side elevation of a width of c. $20 \mathrm{~cm}$ was explored in front of the entrance to the oven (fig. 4). It was made of clay with organic admixture and covered with a layer of clay with admixture of sand. 


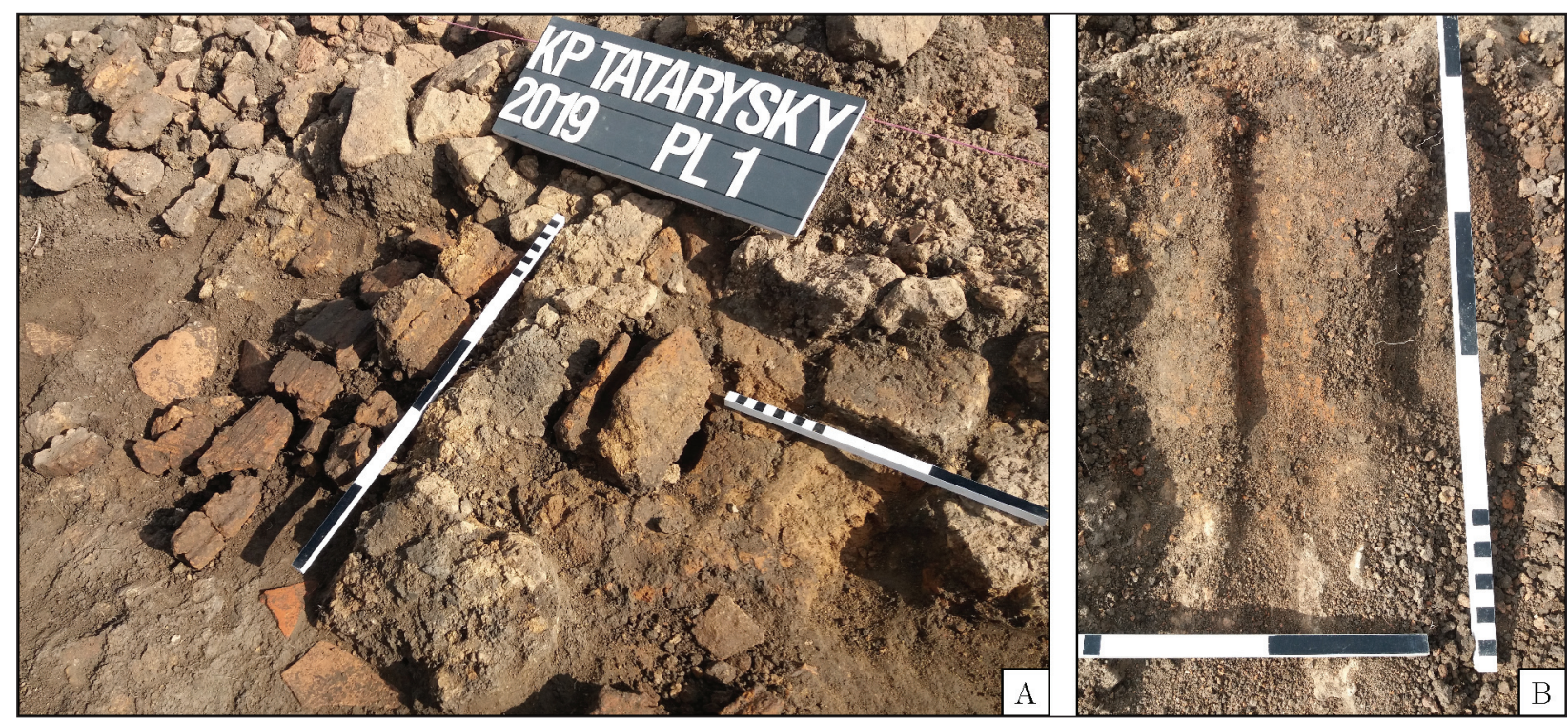

Fig. 3. Kamianets-Podilskyi, Tatarysky, Ploshchadka 1, wooden construction of the floor of the upper storey: A - imprints of wood at the bottom of daub, exploration; B - imprints of daub in the ground, exploration

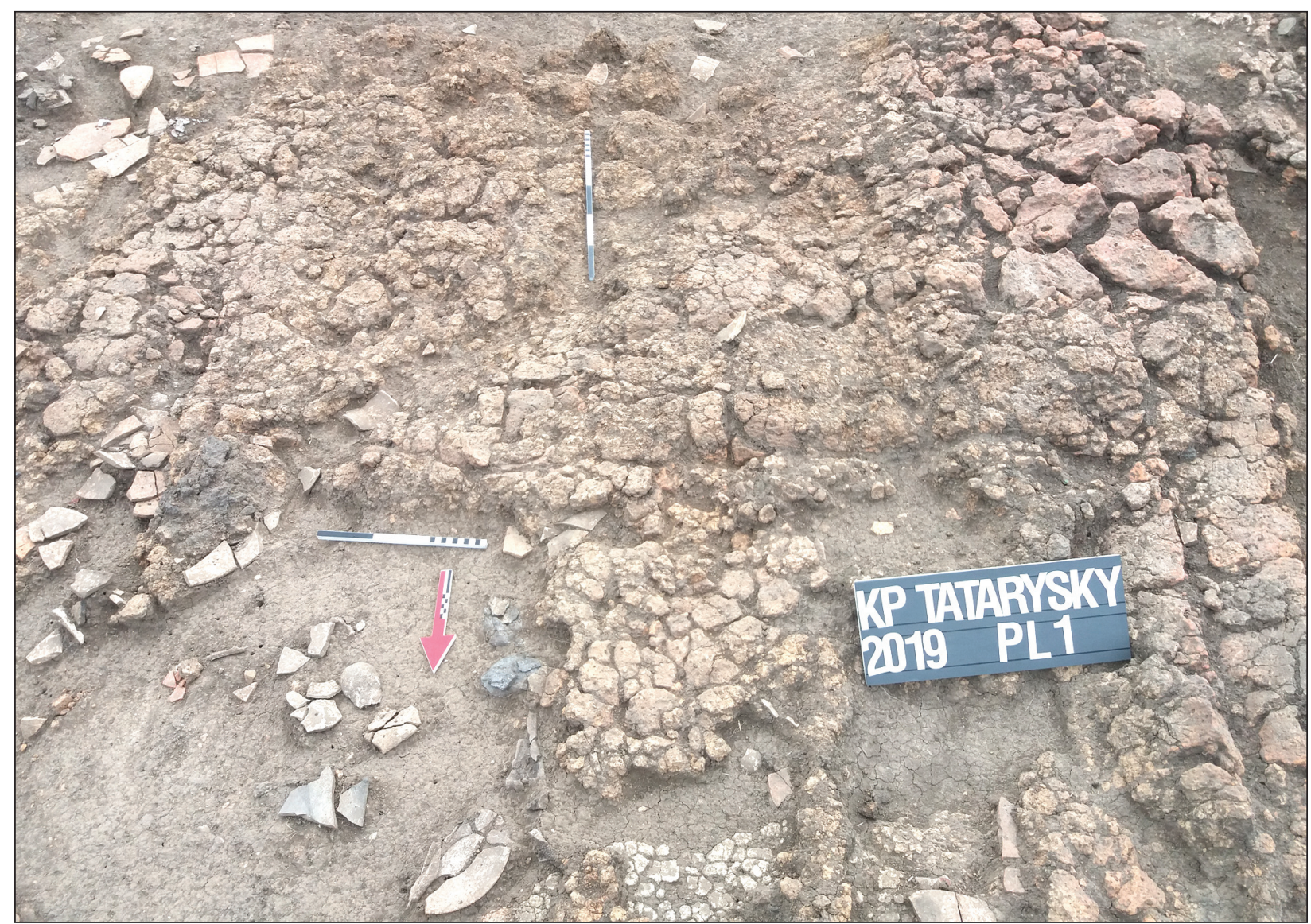

Fig. 4. Kamianets-Podilskyi, Tatarysky, Ploshchadka 1, the oven; view from the north

The other interior element made of clay without organic admixture was located at the short wall of the house, opposite to the entrance to the residential area. Most probably, it was broken during the house collapse. The location of fragments of this interior detail unable the reconstruction of its initial shape and size (fig. 6). The largest fragments of this interior element reach a size of
$12 \times 12 \times 9 \mathrm{~cm}$. Composition of the clay mass of this feature and its location are analogous to the construction details of altars in houses of other Trypillia regions (e. g., Круц 2003; Chernovol 2012). However, we would abandon this and any other interpretation before the increase in databases on Trypillia BII house interiors in the Middle Dniester region. 


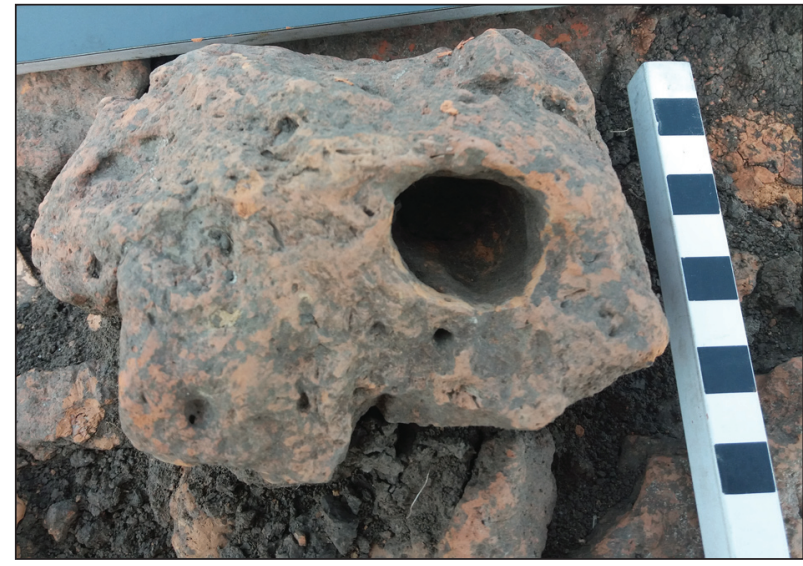

Fig. 5. Kamianets-Podilskyi, Tatarysky, Ploshchadka 1, base of the oven's walls, exploration

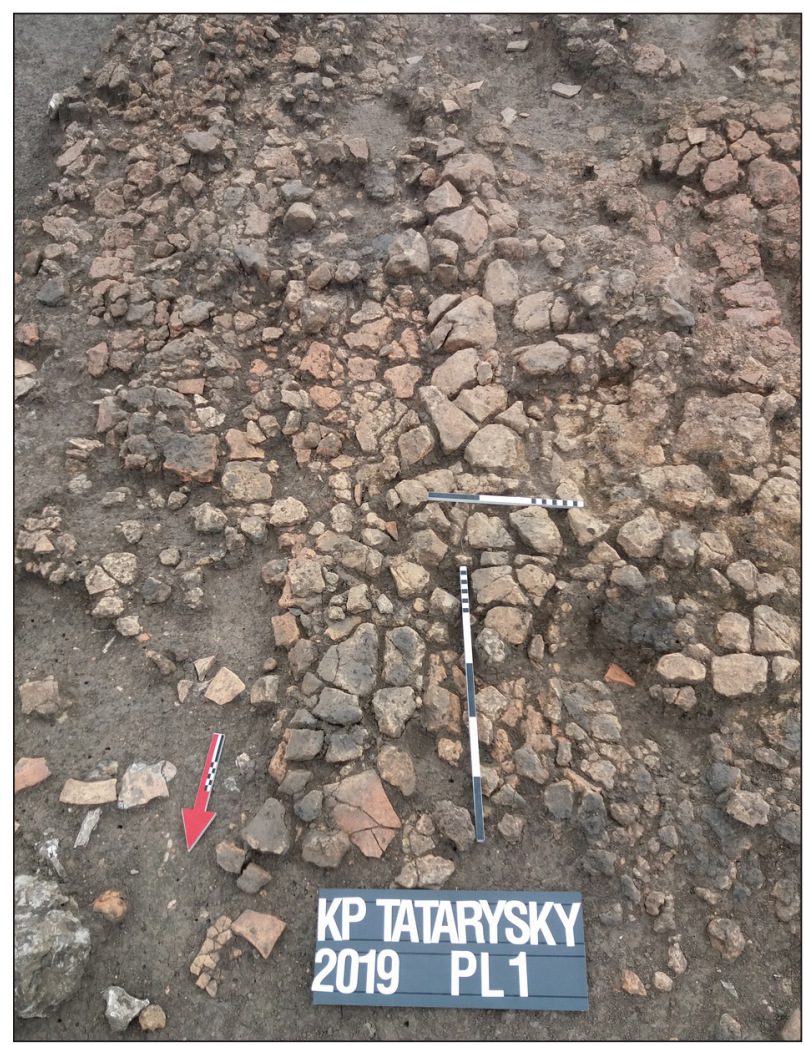

Fig. 6. Kamianets-Podilskyi, Tatarysky, Ploshchadka 1, interior detail near the back wall (an altar?); view from the north

Some fragments of daub and the grinding stone in the entrance room, near its border with the residential area, created a visual impression of the location of a trough in the entrance area (fig. 7). However, this assumption was abandoned with the exploration of ploshchadka showing that the visual impression of the "walls of a through" was created by the vertically standing fragments of daub of the floor of the upper storey.

The lower storey was not subdivided into rooms. Its interior details are represented by a shallow pit and two installations. The first installation made of clay without organic admixtures was relatively thin, up to $2-3 \mathrm{~cm}$. Its preserved

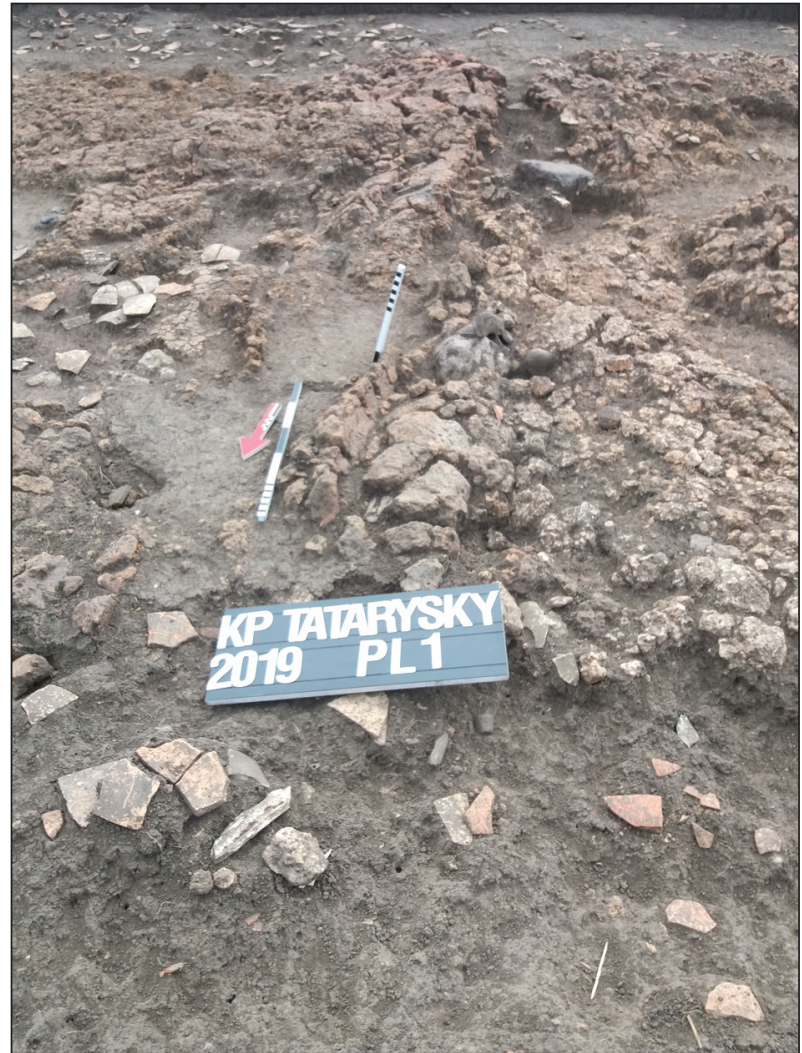

Fig. 7. Kamianets-Podilskyi, Tatarysky, Ploshchadka 1, vertically standing fragments of daub covering the floor of the upper storey, which could be misinterpreted for a trough; view from the north

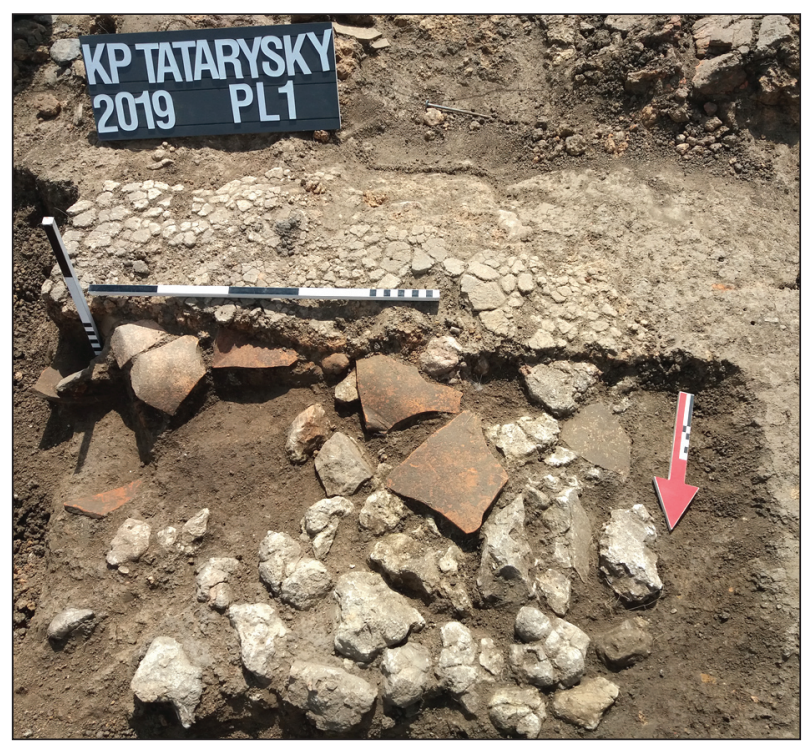

Fig. 8. Kamianets-Podilskyi, Tatarysky, Ploshchadka 1, installation at the ground floor, exploration; view from the north

remains cover an area of c. $1.2 \times 0.7 \mathrm{~m}$. This installation was placed next to a shallow pit located near the north-western corner of the house. Fragments of two bowls were cleaned on the installation (fig. 2, north-western part of the house).

The second installation had more complex structure. The installation had a nearly rectan- 


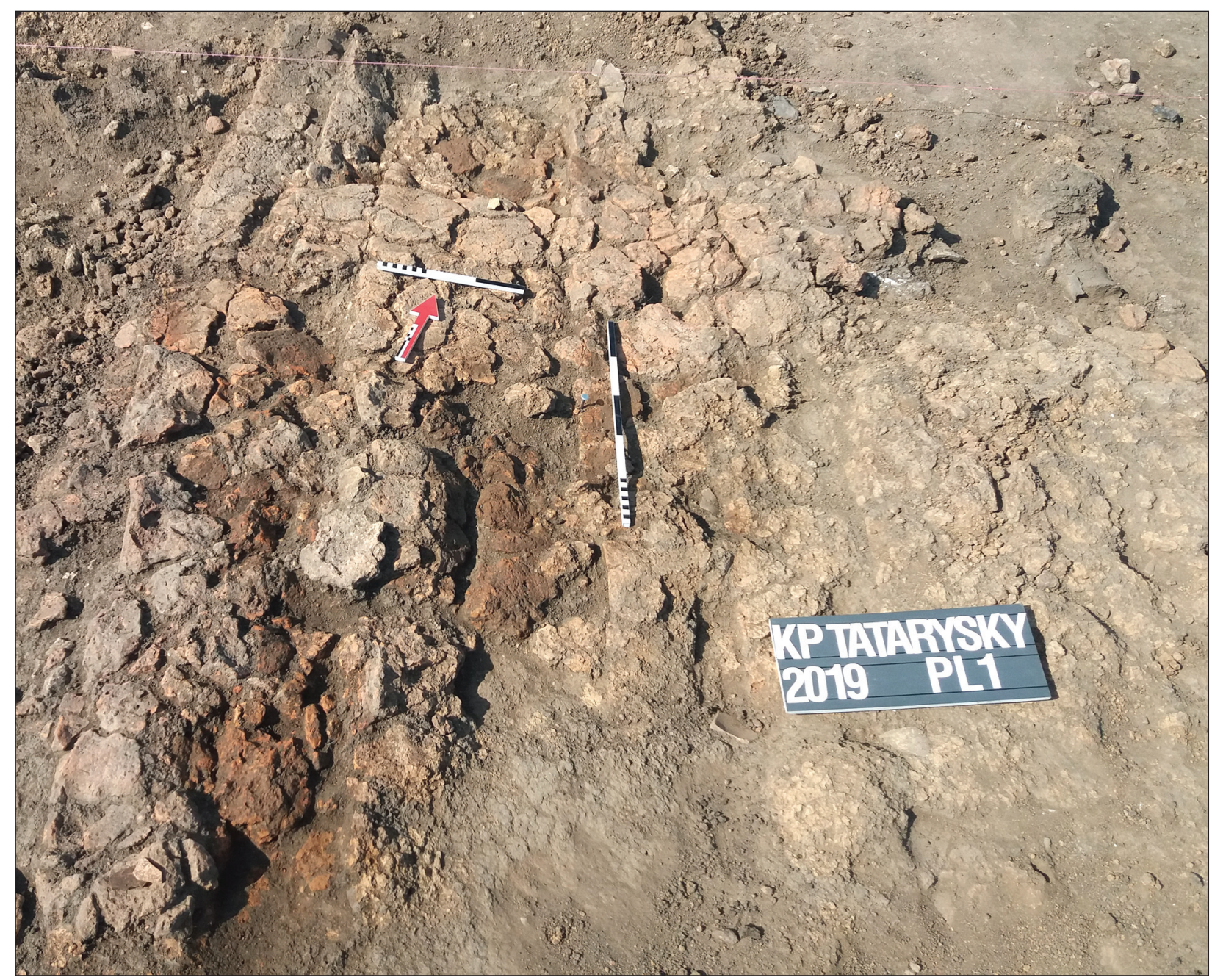

Fig. 9. Kamianets-Podilskyi, Tatarysky, Ploshchadka 1, floor below the oven, exploration; view from the south

gular form of a size of c. $1 \times 0.7 \mathrm{~m}$. The base of this feature was made of stones placed below the level of the ground floor. Pottery sherds were placed above these stones, and then covered by clay without organic admixtures. This layer of clay reached a thickness of $5-7 \mathrm{~cm}$ (fig. 8). Use of stones is a well-known practice of the construction of Trypillia interior details in the Middle Dniester region, where the construction material was accessible (e. g., Маркевич 1981; Черновол 2013; Terna, Hegea 2017).

Exploration of the feature allows some conclusions on house collapse. Considering the shape of Ploshchadka 1, we may assume that different parts of the floor of the upper storey were collapsing when the walls of this house were still standing. In most cases traces of wood were indicated at the bottom side of the daub fragments, and only in a small number of cases the daub fragments "turned» during the house collapse and were laying having traces of wood upwards. This brings us to the idea that the floor of the upper storey collapsed in relatively large parts. Similar to numerous other cases of Trypillia ploshchadkas (e. g., Chernovol 2012), daub of the entrance part was rather preserved in clusters than as a solid layer. This may suggest differences in location of additional fuel or distribution of temperature during the house burning (Chernovol 2012; Johnston et al. 2018).

The lack of daub in the central part of the residential area may suggest that this part of the floor of a size of c. $3 \times 1 \mathrm{~m}$ collapsed first (see the Nebelivka experiment for the analogy: Johnston et al. 2018). Part of this "missed» daub from the empty area in Ploshchadka was found below other daub fragments belonging to the eastern part of the floor of the residential area. Also in this area of Ploshchadka 1 parts of the floor partly covered each other indicating somewhat larger length of the house than it is represented by the length of Ploshchadka 1 . The only solid layer of the significant part of the floor of the upper storey is its part below the oven (fig. 9). This may suggest relatively fast fall of this part of the floor caused by the oven's weight.

Pottery assemblage, stone and flint tools: A brief review. Let us now consider ceramics, stone and flint tools from Ploshchadka 1. Both categories of finds will be precisely analyzed in the forthcoming publications of the Project (as well as archaeozoological and archaeobotanical 
Fig. 10. Kamianets-Podilskyi, Tatarysky, Ploshchadka 1 , examples of pottery: $1,3-$ sphero-conical vessels; 2 - bowl (drawings by D. Kushtan)
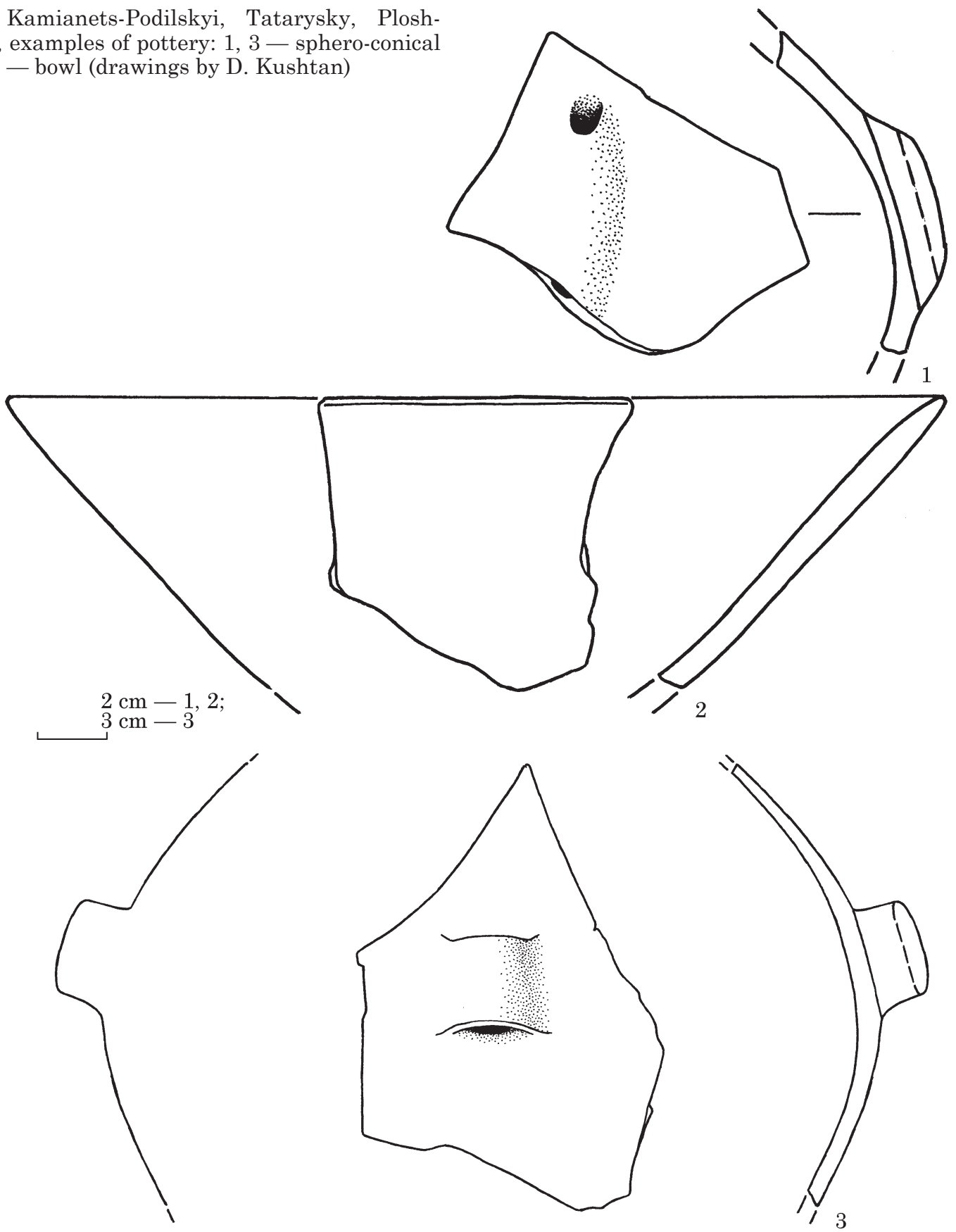

data etc.), so the following section provides the most general characteristics of the collection.

Table pottery was produced of finely dispersed paste or clay with admixture of fine-grained sand. In some cases, admixture of chamotte was noted. Forms include conical and sphero-conical bowls, sphero-conical vessels dominating over biconical vessels, amphorae, craters, pear-shaped vessels, lids, goblets, binocular vessels and pots (figs. 10; 11). Unfortunately, ornamentation was poorly preserved. However, we may admit the domination of the black monochromic painting over the bichromic (black and red) ornamentation. Two fragments from Ploshchadka 1 were ornamented with incisions. Kitchen pottery was made of clay with admixture of sand and mollusk shells or an intensive admixture of sand. Forms are represented by pots and bowls decorated by impression and/or conical or rounded applied elements. Collection of finds also accounts several anthropomorphic figurines, all representing women (fig. 11: 5).

Stone and flint assemblage from Ploshchadka 1 consists of 79 artefacts made of Volhynian flint (36), local flint (18), quartzite (2), sandstone (4). In case of 18 flint items, the raw material they are made of is unrecognized due to deep burning. Group of artefacts related to core preparation, initial core trimming and early stage of core production is rather low - ten items. Group of flake and blade exploitation are quite similar in terms of numbers. The first one consists of 17 flakes 


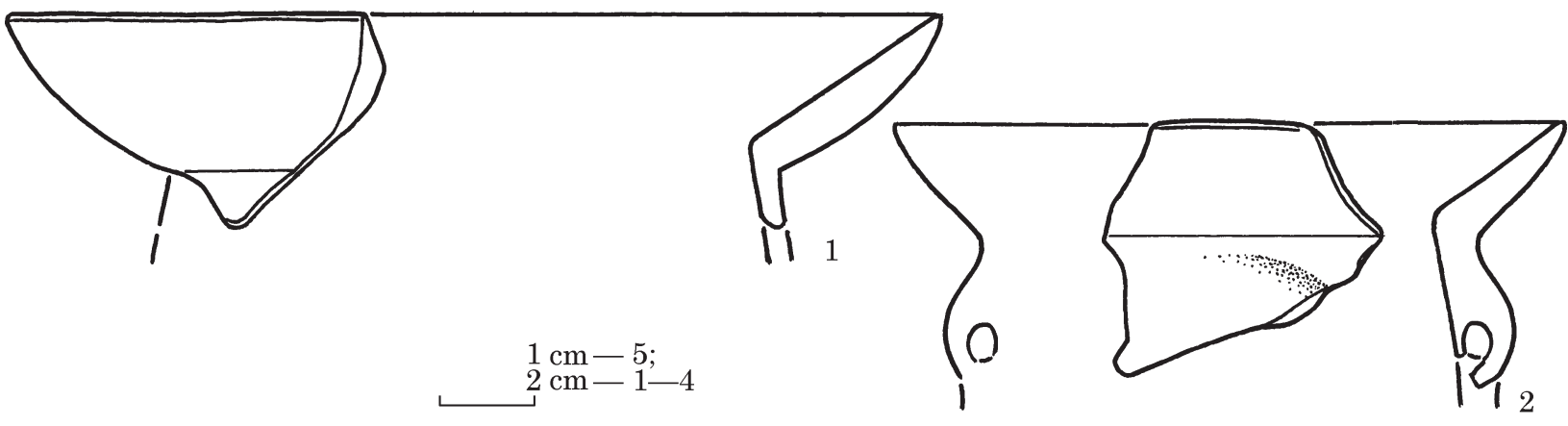

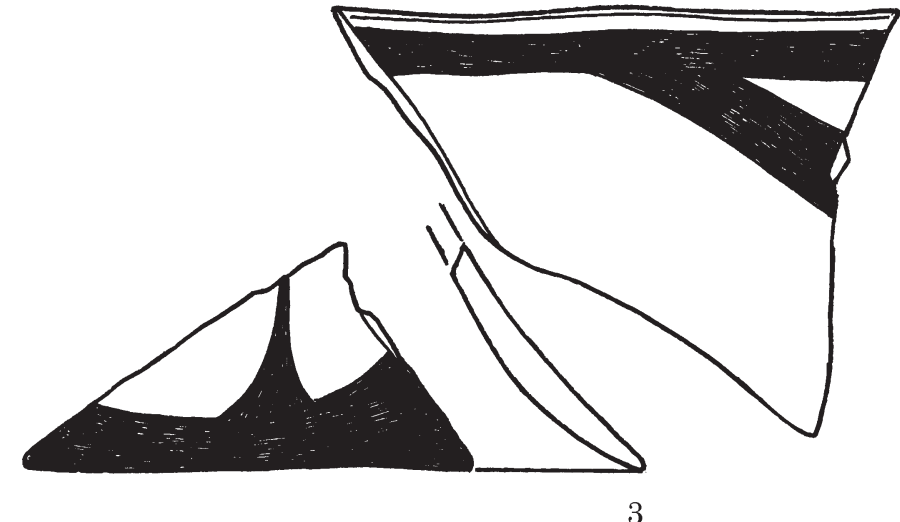

Fig. 11. Kamianets-Podilskyi, Tatarysky, Ploshchadka 1. Examples of pottery: 1, 2- amphoras; 3 - lid; 4 - bowl; 5 - anthropomorphic figurine (drawings by D. Kushtan)

detached from single platform core and the latter one comprises 15 blades detached from single platform core and 1 single platform core for blades, which measures $57 \times 54 \times 40 \mathrm{~mm}$ (fig. 11: 2 ). There is only one platform rejuvenation flake. In a group of undetermined artifacts, waste from core exploitation and retouching are 9 items -1 undetermined flake, 3 chips and 5 chunks.

The most numerous is the group of tools -25 artefacts, which is almost $32 \%$ of the all assemblage. There are 3 endscrapers (fig. 11: 3), 2 truncations, 1 perforator, 1 partially retouched flake, 11 partially retouched blades (fig. 11: 4-6), 3 retouched blades (fig. 11: 7) and fragment of axe made of sandstone (fig. 11: 1).

Processing of the raw material is based on classic core reduction. The splinter technique was used marginally - only in one case. Unless, the group of flake exploitation is more numerous than the blade one, production was focused on blade blanks. This is indicated by the high share of retouched blades in the tool group. Taking into account the small number of artefacts from the first phase of core processing and the small size of the only core, registered at the Ploshchadka 1, we may assume that flint processing took place in other place at the site or the blade blanks were obtained elsewhere. The high amount of tools is characteristic for domestic unit. Two of the longest blades, measuring $87 \times 19 \times 15 \mathrm{~mm}$ and $92 \times$ $23 \times 8 \mathrm{~mm}$, have sickle glossy. These traces in-

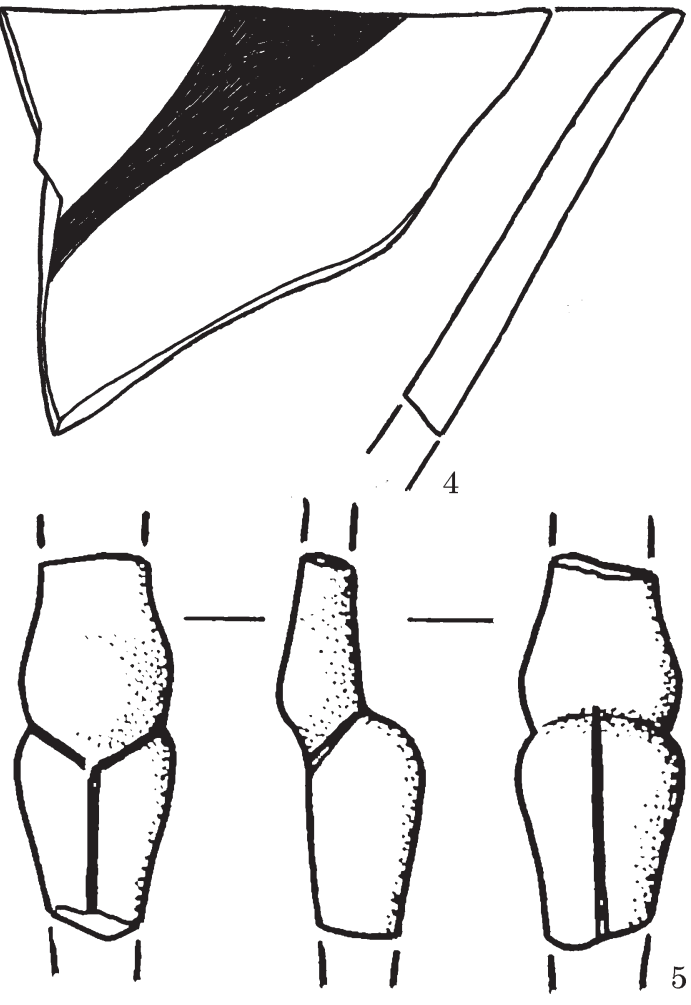

dicate that the tools were used to shear cereals. The function of other tools will be determined by use-wear analysis.

Conclusion and discussion. Thus, the results of our excavation complement the databases on the WTC house construction, location of the interior, and house burning in the Middle Dniester region. Analogies to the location of the interior details are known from the Mereşeuca group settlements and early sites of Petreni group in this area (е. g., Маркевич 1981; Terna, Hegea 2017).

Participation of the populations of Racovăt group and Mereşeuca group (site-types? - we deliberately avoid the discussion on the level of this units in taxonomic hierarchy of the $\mathrm{Cu}$ cuteni-Trypillia cultural complex) in the formation of settlements of Volodymyrivka group and Nebelivka group in the Southern Buh and Dnipro interfluve was already discussed in the literature from the perspective of pottery assemblages (е. g., Попова 1980; Рижов 2007). The results of our excavations and similar features excavated in other WTC areas bring to the conclusion on the 

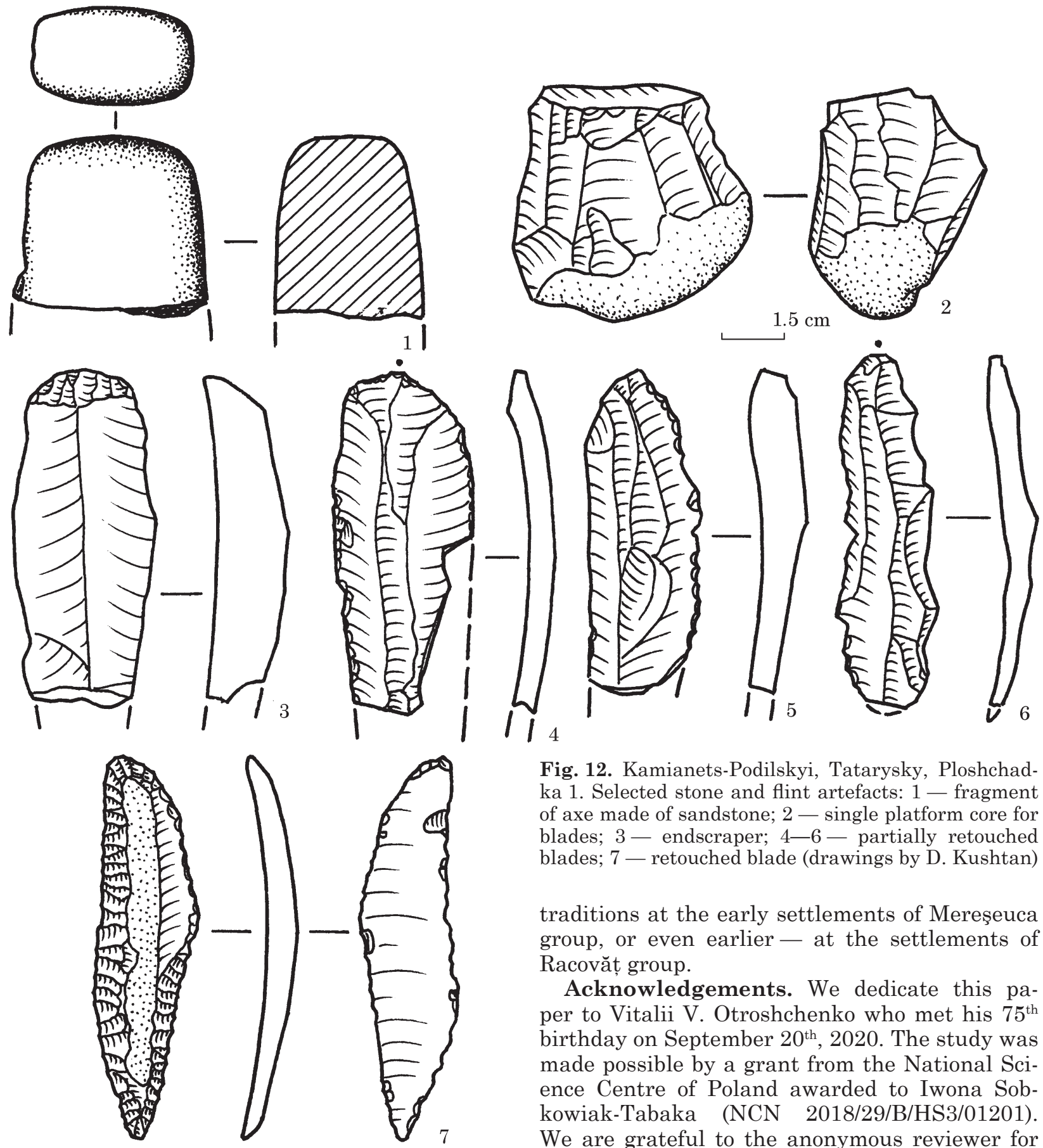

Fig. 12. Kamianets-Podilskyi, Tatarysky, Ploshchadka 1 . Selected stone and flint artefacts: 1 - fragment of axe made of sandstone; 2 - single platform core for blades; 3 - endscraper; 4-6- partially retouched blades; 7 - retouched blade (drawings by D. Kushtan)

traditions at the early settlements of Mereşeuca group, or even earlier - at the settlements of Racovăț group.

Acknowledgements. We dedicate this paper to Vitalii V. Otroshchenko who met his $75^{\text {th }}$ birthday on September $20^{\text {th }}$, 2020. The study was made possible by a grant from the National Science Centre of Poland awarded to Iwona Sobkowiak-Tabaka (NCN 2018/29/B/HS3/01201). We are grateful to the anonymous reviewer for his valuable comments and M. D. Zheliznyk for

additional influence of traditions of Mereşeuca group on house construction techniques known for Volodymyrivka and Nebelivka group sites. According to the location of the interior details, Ploshchadka 1 at Kamianets-Podilskyi, Tatarysky is referred to the variation 6 (upper storey) and variation B (lower storey) of Trypillia houses in the scheme of D. Chernovol (Черновол 2019). Both variations dominate in Volodymyrivka and Nebelivka groups, while a number of houses of the latter is also characterized with a minimal amount or even lack of organic admixture in daub covering the floor of the upper storey (Черновол 2012; 2019). Considering these significant similarities, we may assume the spread of the listed his support in organization of the geophysical survey and excavations at the site. Many thanks are addressed to P. Nechytailo, I. Starenkyi, P. Boltaniuk, O. Bielik, I. Yakhiiev, M. Rozhyk and other members of the team working with us in the field.

\section{ЛIТЕРАТУРА}

Дяченко, О., Собковяк-Табака, І., Левінзон, Є., Нечитайло, П., Старенький, І., Болтанюк, П. 2019. Попередні результати досліджень на трипільському поселенні Кам'янець-Подільський, ур. Татариски. Археологія і фбортифбікація України, 9, с. 18-24.

Круц, В. А. 2003. Трипольские площадки - результат ритуального сожжения домов. В: Корвін- 
Піотровський, О. Г., Круц, В. О., Рижов, С. М. (ред.). Трипільські поселення-гіганти: матеріали міжнародної конференції. Київ: Корвін-Пресс, с. 74-76.

Левінзон, Є. Ю. 2018. Багатошарове поселення Смотрич I (урочище Татариски). В: Кудрина, Ю. (ред.). Історико-культурна спадщина: європейський вилір. Матеріали Всеукраӥнської науково-практичної конфберениії. Львів: Інтерпрінт, с. 82-88.

Левінзон, Є. Ю. 2019. Збори І. С. Винокура з поселення Татариски. В: Копилов, С. А. (ред.). Аpхеологічні дослідження в Украӥні: здобутки $і$ перспективи. Збірник матеріалів VIII студентської археологічної конференцї. Кам'янещь-Подільський: Сисин Я. I., с. 73-84.

Маркевич, В. И. 1981. Позднетрипольские плелена Северной Молдавии. Кишинев: Штиинца.

Отрощенко, В. В. 2015. Відділ археології енеоліту — бронзового віку. В: Толочко, П. П. (ред.). Інсти тут археологї Національної акаделї̈ наук України, 1918-2014. Київ: АДЕФ-Україна, с. 111-125.

Попова, Т. А. 1989. О роли населения Поднестровья в формировании трипольской культуры БугоДнепровского междуречья. В: Березанская, С. С. (ред.). Первобытная археология: материаль и исследования. Киев: Наукова думка, с. 142-148.

Рижов, С. 2003. Трипільські пам'ятки петренської локальної групи Поділля. В: Корвін-Піотровський, О. Г., Круц, В. О., Рижов, С. М. (ред.). Трипільські поселення гіганти: матеріали міжнародної конфбе рениії. Київ: Корвін-Пресс, с. 140-145.

Рижов, С. 2007. Сучасний стан вивчення культурно-історичної спільності Кукутень-Трипілля. В: Рассамакін, Ю., Рижов, С. (ред.). Олег Ольжич. Археологія. Київ: Видавництво ім. Олени Теліги, c. 437-477.

Ткачук, Т. 2015. Контактна зона локальних груп трипільської культури етапів BII і CI на Поділлі. Археологія $і$ фбортифбікація Украӥни, 5, с. 52-57.

Ткачук, Т. 2019. Мальований посуд поселення Незвисько III етапу ВII трипільської культури. Apхеологія $і$ фбортиобікація Украйни, 9, с. 24-30.

Цвек, О. В. 2006. Поселення східнотрипільської культури (короткий нарис). Київ: IA НАН України.

Черновол, Д. 2012. Інтер’ер будівель небелівської локальної групи трипільської культури. Археологія, 1, с. $62-71$.

Черновол, Д. 2013. Постройки петренской локальной группы. Revista arheologică, IX, 1, c. 72-82.

Черновол, Д. 2019. Інтер'єр будівель трипільської культури. Автореферат дисертації к. і. н. Київ: IA НАН України.

Chapman, J. C., Gaydarska, B., Nebbia, M., Millard, A., Albert, B., Hale, D., Woolston-Houshold, M., Johnston, S., Caswell, E., Arroyo-Kalin et al.. 2018. Trypillia mega-sites of the Ukraine (data-set). York: Archaeology Data Service (distributor) https://doi. org/10.5284/1047599

Chernovol, D. 2012. Houses of the Tomashovskaya local group. In: Menotti, F., Korvin-Piotrovskiy, A. G. (eds.). The Tripolye Culture Giant-Settlements in Ukraine: Formation, Development and Decline. Oxford: Oxbow Books, p. 182-209.

Diachenko, A., Sobkowiak-Tabaka, I. 2020. Pottery kilns from the Tripolye settlement of KamianetsPodilskyi, Tatarysky, the 2019 excavation campaign: Regarding the issue of evolution of Tripolye pottery kilns. Sprawozdania Archeologiczne, 72, 1, p. 147-171.

Johnston, S., Diachenko, A., Gaydarska, B., Nebbia M., Voke, P., Bondar, K., Litkevych, V., Chapman,
J. 2018. The experimental building, burning and excavation of a two-storey Trypillia house. In: Turcanu, S. Ursu, C.-E. (eds.). Materiality and Identity in Preand Protohistoric Europe: Homage to Cornelia-Magda Lazarovici. Suceava: Karl A. Romstorfer, p. 397-434.

Rud, V., Zaitseva, O., Hofmann, R., RaubaBukowska, A. and Kosakivskyi, V. 2019. Unique pottery kiln construction? The interpretation of massive clay objects from the Trostianchyk site of the Trypillia culture. Sprawozdania Archeologichne, 71, p. 11-39.

Terna, S., Hegea, S. 2017. Middle and Late Copper Age settlements from the Brinzeni microzone on the Prut river: Older research in a modern background. Sprawozdania Archeologichne, 69, p. 297-325.

\section{REFERENCES}

Diachenko, O., Sobkoviak-Tabaka, I., Levinzon, Ye., Nechytailo, P., Starenkyi, I., Boltaniuk, P. 2019. Poperedni rezultaty doslidzhen na trypilskomu poselenni Kam'ianets-Podilskyi, ur. Tatarysky. Arkheolohiia i fortyfikatsiia Ukrainy, 9, s. $18-24$.

Kruts, V. A. 2003. Trypolskye ploshchadky - rezultat rytualnoho sozhzhenyia domov. In: Korvin-Piotrovskyi, O. H., Kruts, V. O., Ryzhov, S. M. (ed.). Trypilski poselenniahihanty: materialy mizhnarodnoi konferentsii. Kyiv: KorvinPress, s. 74-76.

Levinzon, Ye. Yu. 2018. Bahatosharove poselennia Smotrych I (urochyshche Tatarysky). In: Kudryna, Yu. (ed.). Istoryko-kulturna spadshchyna: yevropeiskyi vymir. Materialy Vseukrainskoi naukovo-praktychnoi konferentsii. Lviv: Interprint, s. 82-88.

Levinzon, Ye. Yu. 2019. Zbory I. S. Vynokura z poselennia Tatarysky. In: Kopylov, S. A. (ed.). Arkheolohichni doslidzhennia v Ukraini: zdobutky i perspektyvy. Zbirnyk materialiv VIII studentskoi arkheolohichnoi konferentsii. Kam'ianets-Podilskyi: Sysyn Ya. I., s. 73-84.

Markevich, V. I. 1981. Pozdnetripolskie plemena Severnoi Moldavii. Kishinev: Shtiintsa.

Otroshchenko, V. V. 2015. Viddil arkheolohii eneolitu bronzovoho viku. In: Tolochko, P. P. (ed.). Instytut arkheolohii Natsionalnoi akademii nauk Ukrainy, 1918-2014. Kyiv: ADEF-Ukraina, s. 111-125.

Popova, T. A. 1989. O roli naseleniia Podnestrovia v formirovanii tripolskoi kultury Bugo-Dneprovskogo mezhdurechia. In: Berezanskaia, S. S. (ed.). Pervobytnaia arkheologiia: materialy $i$ issledovaniia. Kiev: Naukova dumka, s. 142-148.

Ryzhov, S. 2003. Trypilski pam'iatky petrenskoi lokalnoi hrupy Podillia. In: Korvin-Piotrovskyi, O. H., Kruts, V. O., Ryzhov, S. M. (ed.). Trypilski poselennia hihanty: materialy mizhnarodnoi konferentsii. Kyiv: Korvin-Press, s. 140-145.

Ryzhov, S. 2007. Suchasnyi stan vyvchennia kulturno-istorychnoi spilnosti Kukuten-Trypillia. In: Rassamakin, Yu., Ryzhov, S. (ed.). Oleh Olzhych. Arkheolohiia. Kyiv: Vydavnytstvo im. Oleny Telihy, s. 437-477.

Tkachuk, T. 2015. Kontaktna zona lokalnykh hrup trypilskoi kultury etapiv BII i CI na Podilli. Arkheolohiia i fortyfikatsiia Ukrainy, 5, s. 52-57.

Tkachuk, T. 2019. Malovanyi posud poselennia Nezvysko III etapu BII trypilskoi kultury. Arkheolohiia $i$ fortyfikatsiia Ukrainy, 9, s. 24-30.

Tsvek, O. V. 2006. Poselennia skhidnotrypilskoi kultury (korotkyi narys). Kyiv: IA NAN Ukrainy.

Chernovol, D. 2012. Inter'ier budivel nebelivskoi lokalnoi hrupy trypilskoi kultury. Arkheolohiia, 1, s. 62-71.

Chernovol, D. 2013. Postroiki petrenskoi lokalnoi gruppy. Revista arheologică, IX, 1, s. 72-82

Chernovol, D. 2019. Inter'ier budivel trypilskoi kultury. Avtoreferat dysertatsii k. i. n. Kyiv: IA NAN Ukrainy.

Chapman, J. C., Gaydarska, B., Nebbia, M., Millard, A., Albert, B., Hale, D., Woolston-Houshold, M., Johnston, S., Caswell, E., Arroyo-Kalin et al.. 2018. Trypillia mega-sites of the Ukraine (data-set). York: Archaeology Data Service (distributor) https://doi.org/10.5284/1047599

Chernovol, D. 2012. Houses of the Tomashovskaya local group. In: Menotti, F., Korvin-Piotrovskiy, A. G. (eds.). The 
Tripolye Culture Giant-Settlements in Ukraine: Formation, Development and Decline. Oxford: Oxbow Books, p. 182-209.

Diachenko, A., Sobkowiak-Tabaka, I. 2020. Pottery kilns from the Tripolye settlement of Kamianets-Podilskyi, Tatarysky, the 2019 excavation campaign: Regarding the issue of evolution of Tripolye pottery kilns. Sprawozdania Archeologiczne, 72, 1, p. 147-171.

Johnston, S., Diachenko, A., Gaydarska, B., Nebbia, M., Voke, P., Bondar, K., Litkevych, V., Chapman, J. 2018. The experimental building, burning and excavation of a two-storey Trypillia house. In: Țurcanu, S. Ursu, C.-E. (eds.). Materiality and Identity in Pre- and Protohistoric Europe: Homage to Cornelia-Magda Lazarovici. Suceava: Karl A. Romstorfer, p. $397-434$

Rud, V., Zaitseva, O., Hofmann, R., Rauba-Bukowska, A. and Kosakivskyi, V. 2019. Unique pottery kiln construction? The interpretation of massive clay objects from the Trostianchyk site of the Trypillia culture. Sprawozdania Archeologichne, 71, p. 11-39.

Terna, S., Hegea, S. 2017. Middle and Late Copper Age settlements from the Brînzeni microzone on the Prut river: Older research in a modern background. Sprawozdania Archeologichne, 69, p. 297-325.

\section{O. V. Diachenko, I. Sobkowiak-Tabaka, Ye. Yu. Levinzon}

\section{THE WESTERN TRYPILLIA CULTURE HOUSE FROM THE SETTLEMENT OF KAMIANETS-PODILSKYI, TATARYSKY, $3950-3900$ BCE}

This paper aims to introduce the results of excavations of the house remains at the Western Trypillia culture settlement of Kamianets-Podilskyi, Tatarysky in 2019. Ploshchadka 1 belongs to a cluster composed of four houses, which is located in the outer construction ring of the settlement. Ploshchadka had a nearly rectangular shape. This feature reaching a size of c. $11.6 \times$ $4 \mathrm{~m}$ was oriented along the west-east axis with a small northwest - southeast deviation. Layer of burnt daub represents the floor of the upper storey of the house. The floor was composed of relatively thick beams of nearly square or semi-round shape in profile, which supported decks. Wooden construction was covered by two layers of daub. Upper storey was subdivided into two rooms, i. e. the entrance space and residential room. Residential area included an oven and the interior element, which shape and size was not possible to reconstruct. Composition of the clay mass of the latter feature and its location are analogous to the construction details of altars in houses of other Western Trypillia culture regions. Interior of the lower storey is represented by the shallow pit and two installations made of clay. In the eastern part of the residential area, parts of the floor partly covered each other indicating somewhat larger length of the house than it is represented by the length of Ploshchadka 1. According to the location of the interior details, Ploshchadka 1 at Kamianets-Podilskyi, Tatarysky is referred to the variation 6 (upper storey) and variation B (lower storey) of Trypillia houses in the scheme of D. Chernovol. Analogies to the Ploshchadka 1 from other areas of the Western Trypillia culture made possible some conclusions on the influence of the Middle Dniester traditions on house construction techniques in the Southern Buh and Dnipro interfluve.

Keywords: Cucuteni-Trypillia cultural complex, Western Trypillia culture, ploshchadka, house, interior.
О. В. Дяченко, I. Собковяк-Табака, Є. Ю. Левінзон

\section{ЗАХІДНОРИПІЛЬСЬКЕ ЖИТЛО З ПОСЕЛЕННЯ КАМ'ЯНЕЦЬ- ПОДІЛЬСЬКИЙ, ур. ТАТАРИСКИ, 3950 - 3900 рр. до н. е.}

Запропоновану роботу присвячено введенню до наукового обігу результатів розкопок залишків житла на поселенні західнотрипільської культури Кам'янецьПодільський, ур. Татариски. Площадка 1 належить до групи із чотирьох споруд у зовнішньому еліпсі забудови поселення. Форма площадки була близькою до прямокутної, із лакуною посередині. Об’єкт розмірами $11,6 \times$ 4,0 м був оріентований за лінією захід-схід, із невеликим відхиленням на північний захід - південний схід. Шар випаленої глиняної обмазки є залишками підлоги другого поверху споруди. Каркас ціеї підлоги був зроблений із дерев'яних брусів і кругляка, які підтримували дошки. Дерев'яну конструкцію перекривали два шари глиняної обмазки, перший - iз незначними рослинними домішками, другий — майже без них. Другий поверх був поділений на два примішення - вхідне та житлове. В останньому виявлено піч та елемент інтер'єру, форму та розміри якого встановити не вдалося. Склад глиняної маси та розташування останнього відповідає конструкції та розташуванню вівтарів у інших регіонах поширення західнотрипільської культури. Інтер'ер першого поверху представлений неглибокою ямою та двома вимостками, виконаними із глиняної маси без рослинних домішок. У східній частині житлового приміщення фрагменти підлоги лежали перекриваючи один одного краями, що вказуе на більшу довжину будівлі, ніж її передає довжина площадки. Відповідно до розташування елементів інтер'єру, площадка 1 відноситься до варіанту 6 (другий поверх) та варіанту В (перший поверх) за схемою Д. Черновола. Аналогії площадџі 1 із Кам'янцяПодільського, ур. Татариски з інших регіонів поширення західнотрипільської культури дають можливість зробити висновки щодо впливу традищій населення Середнього Подністров'я на трипільське домобудівництво у межиріччі Південного Бугу та Дніпра.

Ключові слова: культурний комплекс КукутеньТрипілля, західнотрипільська культура, площадка, житло, інтер'єр.

Одержано 21.09.2020

ДЯЧЕНКО Олександр Вікторович, кандидат історичних наук, старший науковий співробітник, Інститут археології НАН України, Київ, Україна.

DIACHENKO Aleksandr, $\mathrm{PhD}$, Senior Researcher, National Academy of Sciences of Ukraine, Institute of Archaeology, Kyiv, Ukraine.

ORCID: 0000-0002-6959-2919,

e-mail: adiachenko@iananu.org.ua.

ЛЕВІНЗОН Свгеній Юрійович, магістрант, Національний університет «Киево-Могилянська академія», Кииів, Україна.

LEVINZON Yevhenii, graduate student, National University of "Kyiv-Mohyla Academy», Kyiv, Ukraine. ORCID: 0000-0003-4356-0430,

e-mail: yevhenii.levinzon@ukma.edu.ua.

СОБКОВЯК-ТАБАКА Івона, Д-р Хаб., ас. Профресор, університет ім. Адама Міщкевича у Познані, Польща. SOBKOWIAK-TABAKA Iwona, Dr. Hab, Associate Professor, Adam Mickiewicz University in Poznań, Poland. ORCID: 0000-0001-5913-1177, e-mail: iwosob@amu.edu.pl. 